\title{
Loss of protein expression of hMLH1 and hMSH2 with double primary carcinomas of the stomach and colorectum
}

\author{
MANABU YAMAMOTO ${ }^{1,5}$, KENICHI TAGUCHI ${ }^{2}$, HIDEO BABA $^{3}$, KAZUYA ENDO $^{4}$, \\ SHUNJI KOHNOE ${ }^{4}$, TAKESHI OKAMURA ${ }^{4}$ and YOSHIHIKO MAEHARA ${ }^{1}$ \\ ${ }^{1}$ Department of General Surgery, Graduate School of Medical Sciences, Kyushu University, 3-1-1 Maidashi, Higashi-ku, \\ Fukuoka 812-8582; ${ }^{2}$ Department of Pathology, National Kyushu Cancer Center, 3-1-1 Notame, Minami-ku, \\ Fukuoka 811-1395; ${ }^{3}$ Department of Gastroenterological Surgery, Graduate School of Medical Sciences, \\ Kumamoto University, 1-1-1 Honjo, Kumamoto 860-8556; ${ }^{4}$ Department of Gastroenterological Surgery, \\ National Kyushu Cancer Center, 3-1-1 Notame, Minami-ku, Fukuoka 811-1395, Japan
}

Received December 27, 2005; Accepted March 17, 2006

\begin{abstract}
The frequency of synchronous or metachronous multiple primary carcinomas in patients with gastrointestinal carcinoma or colorectal carcinoma (CRC) has been reported to be $\sim 10 \%$. We determined the role of hMSH2 and hMLH1 in double carcinomas with both GC and CRC. Fifty-six patients with synchronous or metachronous colorectal carcinoma with gastric carcinoma (CRC with GC), and 69 patients with CRC alone was included in our study. We investigated their clinicopathological characteristics, family history and immunohistochemical stains of hMSH2 and hMLH1 were compared between the patients with CRC alone and those with both CRC with GC. The defective protein expression of hMSH1 and/or hMLH1 in colorectal carcinomas was significantly higher in patients with both CRC with GC than in those with CRC alone $(\mathrm{p}<0.0001)$. The survival rate in patients with both CRC with $\mathrm{GC}$ was significantly lower than that in those with $\mathrm{CRC}$ alone $(\mathrm{p}<0.01)$, in addition, the survival rate in patients with defective protein expression of $\mathrm{hMSH} 2$ and/or hMLH1 was higher than in those with a positive protein expression of hMSH2 and/or hMLH1 in CRC with GC $(\mathrm{p}<0.05)$. The incidence of defective protein expression of hMSH2 and/or hMLH1 in CRC with GC
\end{abstract}

Correspondence to: Dr Manabu Yamamoto, ${ }^{5}$ Present address: Department of Surgery, Hiroshima Red Cross Hospital and Atomic Bomb Survivor Hospital, 1-9-6 Senda-machi, Naka-ku, Hiroshima 730-8619, Japan

E-mail: mayama@hiroshima-med.jrc.or.jp

Abbreviations: HNPCC, hereditary nonpolyposis colorectal carcinoma; CRC, colorectal carcinoma; GC, gastric carcinoma; MGC, multifocal gastric carcinoma; SGC, single focal gastric carcinoma; MSI, microsatellite instability; MSS, microsatellite stable; MSI-H, high level of microsatellite instability; MSI-L, low level of microsatellite instability; MMR, DNA mismatch repair; RER, replication errors

Key words: gastric carcinoma, colorectal carcinoma, familial, $\mathrm{MSH}, \mathrm{MLH}$, microsatellite instability patients suggests that abnormalities in the function of $\mathrm{hMSH} 2$ and hMLH1 may play an important role in carcinogenesis. Our findings indicate that the CRC patients who demonstrate a defective protein expression of hMSH2 and/or hMLH1 have a higher risk of developing secondary carcinoma in the gastrointestinal tract.

\section{Introduction}

The general frequency of multiple primary carcinomas has been reported to be $10 \%$ in Japan and in other countries $(1,2)$. In particular, the frequency of synchronous or metachronous carcinomas of colorectum and lung was higher than other cancers $(1,3)$. In previous studies, the prognosis of these patients was usually influenced by the site of the second primary carcinoma (4). However, the biologic nature and the prognosis of multiple primary carcinomas by itself were not clarified.

Over the past decade, the most thoroughly documented hereditary carcinoma has been hereditary nonpolyposis colorectal carcinoma (HNPCC). HNPCC is now recognized as an autosomal dominant carcinoma susceptibility syndrome frequently caused by a germ line mutation in DNA mismatch repair (MMR) genes. To date, germ line mutations in hMSH2 and hMLH1 account for up to $90 \%$ of all reported MMR gene mutations in HNPCC kindreds $(5,6)$. One of the first successful efforts of the International Collaborative Group on HNPCC (ICG-HNPCC) at its meeting in Amsterdam in 1990 was the establishment of a set of selection criteria for families with HNPCC (Lynch syndrome, Amsterdam criteria I) (7). However, some investigators feel that these criteria exclude some classic HNPCC families because they do not take into account the extracolonic cancers that are also a part of this syndrome, and the evaluation of the literature on the tumor spectrum of HNPCC indicated that cancers of the endometrium, stomach, ovaries, small bowel, ureter, renal pelvis, brain, and hepatobiliary tract are all associated with HNPCC (8-12). Among these tumors, cancers of endometrium, ureter, renal pelvis and small bowel have the highest relative risk, and therefore, they tend to be the most specific for HNPCC. The revised ICG-HNPCC criteria (Amsterdam criteria II) included 
Table I. Clinicophathological findings in CRC alone or CRC with GC.

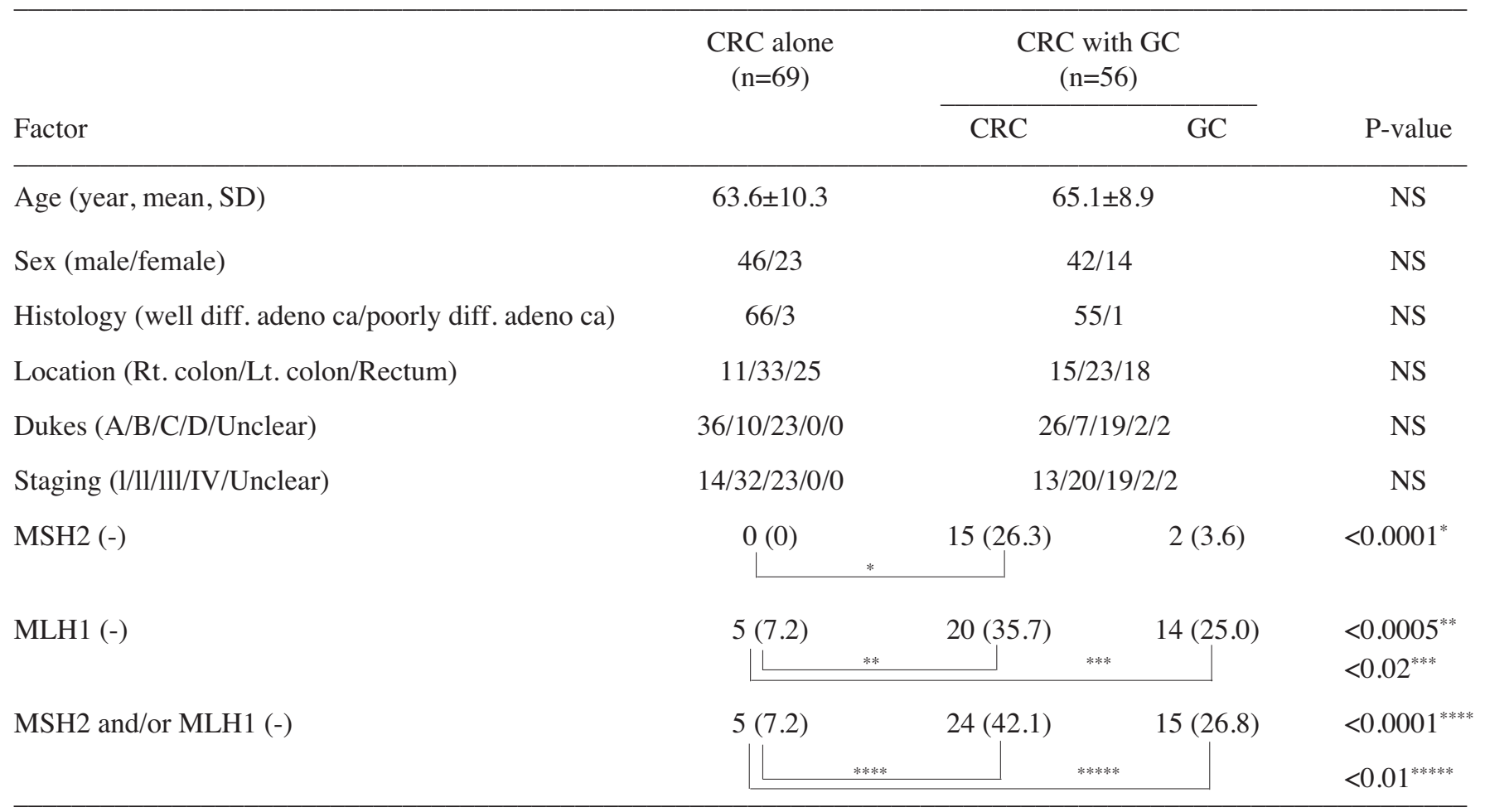

CRC alone, colorectal carcinoma alone; CRC with GC, colorectal carcinoma with gastric carcinoma; GC, gastric carcinoma; values represent the number of patients, with the percentages in parentheses; NS, not significant; ${ }^{*},{ }^{*}, * * * * * * * * * * *{ }^{*}{ }^{*}$ significant difference.

HNPCC-associated cancer (cancer of endometrium, ureter, renal pelvis and small bowel). According to numerous data, the causes of the development of colorectal carcinoma with gastric carcinoma (CRC with GC) have not been clarified. One hypothesis involves the loss of DNA MMR in the carcinogenesis of CRC with GC, which belongs to an HNPCCassociated cancer. The other is not influenced by DNA MMR.

The objective of this study is to clarify the characteristics of patients with $\mathrm{CRC}$ with GC, and compare the findings with patients demonstrating colorectal carcinoma (CRC) alone. In addition to the general clinicopathologic characteristics, we also investigated the family history of cancer and the immunohistochemical protein expression of hMSH2 and hMLH1, in order to clarify whether or not GC should be considered a type of HNPCC-associated cancer in patients demonstrating CRC with GC.

\section{Materials and methods}

Patients. The subjects of our study consisted of 125 CRC patients with or without GC who underwent a colorectal resection and gastrecomy combined with lymph node dissection at the National Kyushu Cancer Center between 1974 and 1999. Fifty-six patients underwent a surgical resection for both GC and CRC (age; 47-85 years). Thirty-one of 56 patients had synchronous and the other 25 patients had metachronous multiple primary carcinomas. Sixty-nine Japanese patients were selected from 1745 patients who underwent a surgical resection between 1974 and 1999 due to CRC without GC as control subjects (age; 39-82 years). The control subjects for each patient were chosen based on similar gender, age, Dukes stage and the location of tumor. The age was based on the occurrence of the first carcinoma.

All resected specimens were microscopically examined for the histologic type, the depth of invasion, and the presence of lymph node metastasis according to the TNM classification of stomach and colorectum (UICC)-5th English edition (13). The diagnostic criteria of multiple primary carcinomas were based on those of Warran et al (14): 1) the existence of carcinoma; 2) the presence of carcinomas in separate locations; 3 ) one carcinoma was not a metastatic lesion of another carcinoma. The diagnostic criteria for synchronous multiple gastric carcinoma (MGC) was also based on those of Moertel et al (15): 1) each lesion had to be a pathologically proven malignancy; 2) all lesions had to be separated by an interval of a microscopically normal gastric wall; and 3) the possibility that one of the lesions represented a local extension or metastatic tumor had to be ruled out beyond any reasonable doubt.

Immunohistochemical study. Immunohistochemical analyses for expressions of hMSH2 and hMLH1 proteins were performed on 4 - $\mu$-thick formalin-fixed paraffin-embedded tissue sections of colorectal and gastric carcinomas, using Dako EnVision $^{\mathrm{TM}}+$ System, HRP (DAB) (DakocytomationCalifornia Inc., Carpinteria, CA). The sections were deparaffinized in xylene and dehydrated through graded alcohol to water. The sections were immersed in Dako target retrieval solution high $\mathrm{pH}, \mathrm{pH} 10.0$, and were subjected to heatinduced antigen retrieval in a water bath, $98^{\circ} \mathrm{C}$ for $40 \mathrm{~min}$, and then were cooled slowly at room temperature for $20 \mathrm{~min}$. 

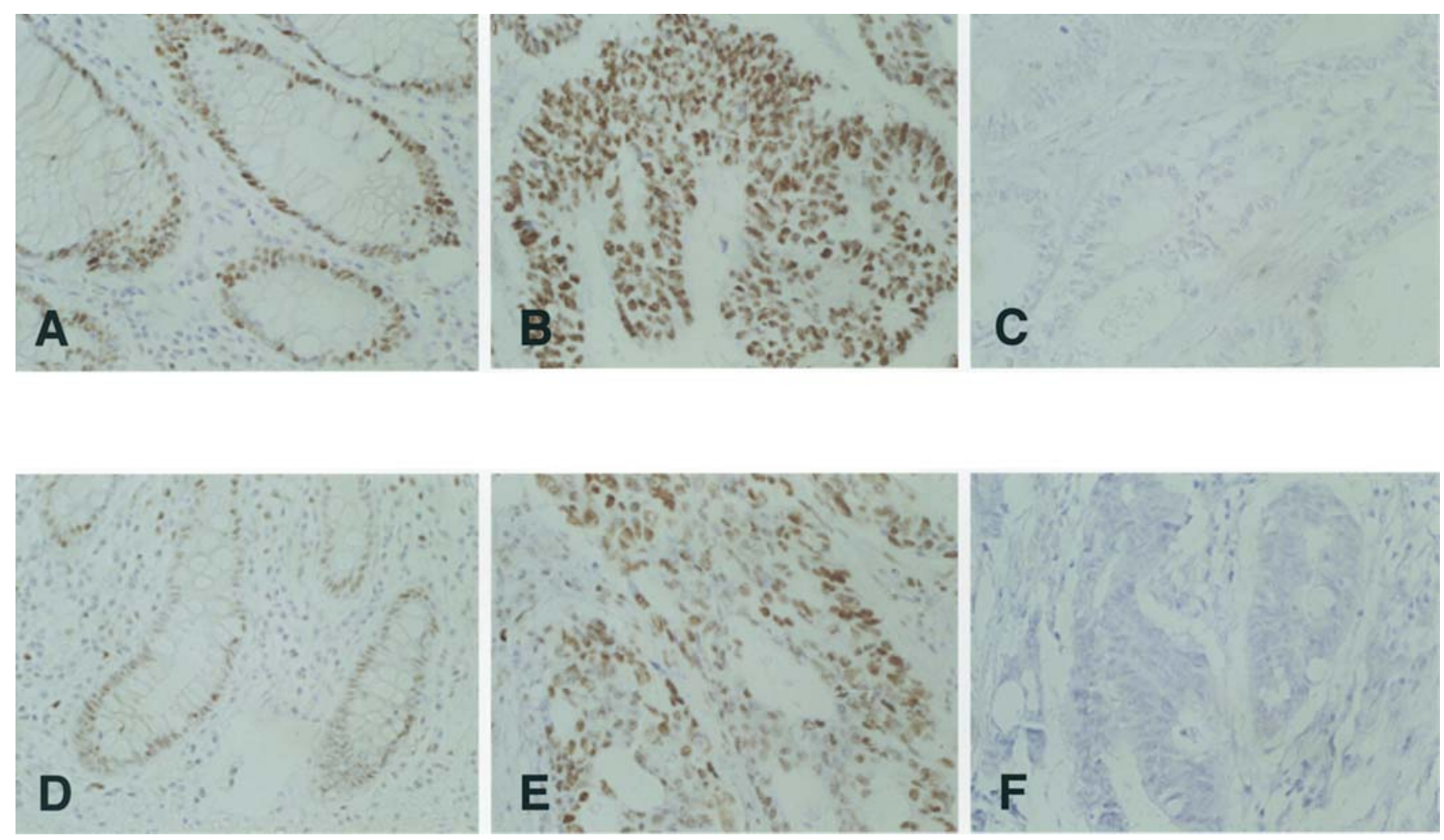

Figure 1. Immunohistochemical staining for hMSH2 and hMLH1 proteins. Sections were stained using antibodies for either hMSH2 (A-C) or hMLH1 (D-F). (A and D) Normal tissue specimens. (B and D) Tumor tissue specimens in a case with CRC alone. (C and F) Tumor tissue specimens in a case with CRC with GC.

The endogenous peroxidase activity was blocked by incubation with blocking solution, $0.03 \% \mathrm{H}_{2} \mathrm{O}_{2}$ and sodium azide, and specimens were washed in TBS, $50 \mathrm{mmol} / \mathrm{l}$ Tris$\mathrm{HCl}, 150 \mathrm{mmol} / \mathrm{l} \mathrm{NaCl}, \mathrm{pH}$ 7.6. The sections were incubated overnight at $4^{\circ} \mathrm{C}$ with one of the following mouse monoclonal antibodies: clone FE11 (antibody against MSH2; 1:33; Oncogene Research Products, USA): clone G168-15 (antibody against MLH1; 1:33; BD Biosciences, USA), diluted by Dako antibody diluent with background reducing component. After rinsing 3 times with TBS, the sections were incubated with polymer solution, the HRP-labeled dextran polymer conjugated to goat polyclonal anti-mouse immunoglobulin antibody for $60 \mathrm{~min}$ at room temperature. The sections were washed 3 times with TBS. Finally, the sections were incubated with diaminobenzidine and $\mathrm{H}_{2} \mathrm{O}_{2}$, counterstained in hematoxylin, washed in tap water, dehydrated through graded alcohol, cleared in xylene, and cover-slipped. Negative controls consisted of substituting Dako antibody diluent with background reducing components without the primary antibodies for each immunostain.

Immunohistochemical analyses for the protein expression of hMSH2 and hMLH1 were performed on the mucosa of the stomach and colon from patients who underwent a colectomy or gastrectomy for benign disease. The normal musoca was used as a positive control for the expressions of hMSH2 and hMLH1.

The immunohistochemical protein expression of hMSH2 and hMLH1 was evaluated independently by two observers. A total of 1000 tumor cells in five representative high power fields (200 tumor cells for each field) were counted under a photomicroscope. The score from each individual case was determined as the average of the results recorded by the two observers. The overall extent of immunoreaction was expressed using the following criteria for the expression of hMSH2 and hMLH1: $0-5 \%$ staining was considered to be a negative finding, while anything $>5 \%$ was regarded to indicate positive staining.

Statistical analysis. Differences among the groups were determined using Student's t-test. The survival curve of the patients was determined according to the Kaplan-Meier method. The significance of differences in the survival between the two groups was tested using the log-rank (Mentel-Cox) test. StatView-5.0 Software (SAS Institute, Cary, NC, USA) was used to perform all statistically analyses. A value of $\mathrm{p}<0.05$ was considered to be statistically significant.

\section{Results}

Immunohistochemical protein expression of hMSH2 and hMLH1 in CRC alone and CRC with GC. The clinicopathological findings of patients in CRC with GC were compared with patients in CRC alone (Table I). There are no statistically significant differences in the two groups.

Fig. 1 shows the immunohistochemical staining for hMSH2 and hMLH1 of normal and colorectal carcinoma tissues in both CRC alone and CRC with GC. The protein expression of hMSH2 and hMLH1 was maintained in the CRC tissue specimens in most patients with CRC alone. In Table I, the loss of the protein expression for hMSH2 in CRC with GC was significantly more frequent than that in CRC alone (0\%:26.3\%, p<0.0001, Fig. 1B and C). Similarly, the loss 
Table II. Clinicophathological findings with or without hMSH2 and/or hMLHl(-) in CRC with GC.

\begin{tabular}{|c|c|c|c|}
\hline $\begin{array}{l}\text { CRC with GC } \\
(n=56)\end{array}$ & $\begin{array}{l}\text { hMSH2 and/or hMLH1(-) } \\
\qquad(\mathrm{n}=24)\end{array}$ & $\begin{array}{l}\mathrm{hMSH} 2 \text { and hMLH1(+) } \\
\qquad(\mathrm{n}=32)\end{array}$ & p-value \\
\hline Age (year, mean, SD) & $64.7 \pm 10.5$ & $65.3 \pm 7.6$ & NS \\
\hline Sex (male/female) & $19 / 5$ & $23 / 9$ & NS \\
\hline Histology (well diff. adeno ca/poorly diff. adeno ca) & $24 / 0$ & $31 / 1$ & NS \\
\hline Location (Rt. colon/Lt.colon/Rectum) & $5 / 9 / 10$ & $10 / 15 / 7$ & NS \\
\hline Dukes (A/B/C/D/Unclear) & $10 / 5 / 8 / 1 / 0$ & $16 / 2 / 11 / 1 / 2$ & NS \\
\hline Staging (I/I 1/11 I/I V/Unclear) & $4 / 11 / 8 / 1 / 0$ & $9 / 9 / 11 / 1 / 2$ & NS \\
\hline
\end{tabular}

CRC with GC, colorectal carcinoma with gastric carcinoma; values represent the number of patients, with the percentages in parentheses; NS, not significant.

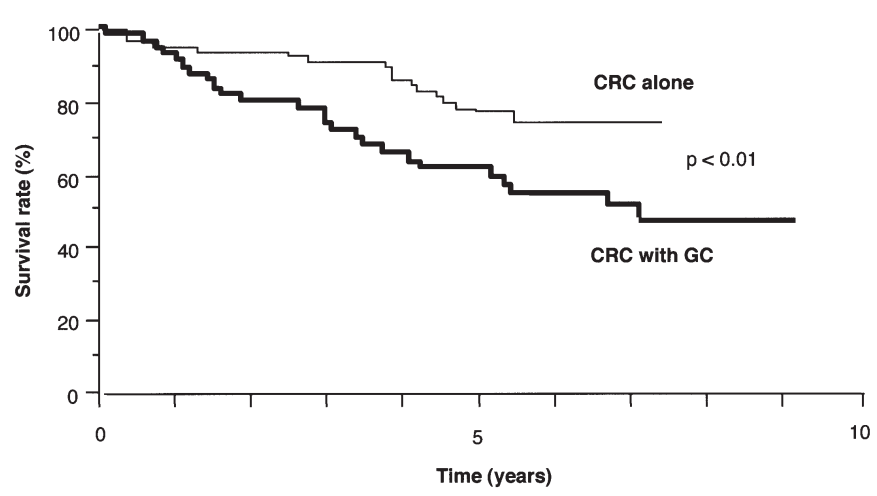

Figure 2. The prognostic value in CRC with or without GC. Kaplan-Meier curves of the disease-free survival for patients with CRC alone $(n=69)$ and CRC with GC $(n=56)$ are shown.

of the protein expression for hMLH1 in CRC with GC was significantly more frequent than that in CRC alone $(7.2 \%: 35.7 \%, \mathrm{p}<0.0005$, Fig. $1 \mathrm{E}$ and F). In particular, the loss of protein expression for hMSH2 and/or hMLH1 of CRC in patients with both CRC with GC was significantly more frequent that in CRC alone (7.2\%:42.1\%, p<0.0001).

Survival in CRC alone and CRC with GC. Fig. 2 shows the survival rates of the two groups, and the survival rate in the CRC alone group was significantly higher than that in the CRC with GC group ( $\mathrm{p}<0.01)$.

The clinicopathological findings of patients with a loss of protein expression for hMSH2 and/or hMLH1 were compared with patients showing a positive protein expression for hMSH2 and/or hMLH1 (Table II). The age, the location of tumor, and Dukes stage showed no statistically significant differences between the two groups. The survival rate in patients with loss of protein expression of hMSH2 and/or hMLH1 was significantly more higher than that in those showing a positive protein expression for hMSH2 and hMLH1 among the CRC with GC patients (p<0.05, Fig. 3).

Family history of cancer in CRC alone and CRC with GC. We investigated the family history of cancer in patients with both CRC alone and CRC with GC (Table III). There was no

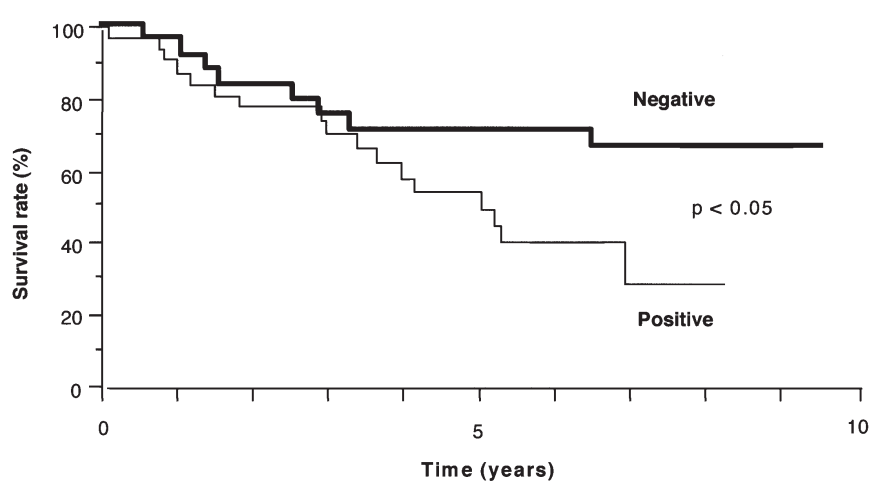

Figure 3. The prognostic value in CRC with GC. Kaplan-Meier curves of survival for patients with defective protein expression of hMSH2 and/or hMLH1 $(n=24)$ and protein expression of hMSH2 and/or hMLH1 $(n=32)$ are shown. Negative, a defective protein expression of hMSH2 and/or hMLH1; Positive, a positive protein expression of hMSH2 and/or hMLH1.

difference in the frequency of a positive family history of cancer between CRC alone group and $\mathrm{CRC}$ with $\mathrm{GC}$ group (30 of 69 vs. 19 of 56). There was also no difference in the age of patients with or without a family history of cancer. However, the loss of a protein expression for hMSH2 and/or hMLH1 in patients, who were aged $<65$ years was the most frequent among the patients demonstrating CRC with GC (12 of 23, 52.2\%, Table III).

The types of cancer among family members were examined in the two groups (Table IV). The types of cancer among the family members in CRC alone group were gastric, lung, and liver, while those in $\mathrm{CRC}$ with $\mathrm{GC}$ were gastric, uterus, and colon. Of note, GC was most frequently observed in family members demonstrating both $\mathrm{CRC}$ with $\mathrm{GC}$ and $\mathrm{CRC}$ alone. The number of GCs is the largest among all the family history cancer types (Table IV) because GC is the most common cancer in Japan. The frequency of a loss of a protein expression for hMSH2 and/or hMLH1 in the family history of cancer in CRC alone was lower than that in those demonstrating CRC with GC. In particular, the frequency of a loss of a protein expression for hMSH2 and/or hMLH1 was high in patients with a family history of cancer in the colorectum and uterus carcinomas of family members among CRC with GC group (Table IV). 
Table III. Relationship between family history of cancer and defective protein expression of hMSH2 and/or hMLH-1 in CRC alone or CRC with GC.

\begin{tabular}{|c|c|c|c|c|c|c|c|}
\hline \multirow{3}{*}{$\begin{array}{l}\text { Family history } \\
\text { Negative }\end{array}$} & & \multicolumn{3}{|c|}{ CRC alone } & \multicolumn{3}{|c|}{ CRC with GC } \\
\hline & & \multirow{2}{*}{$\begin{array}{c}\text { Total } \\
39\end{array}$} & \multicolumn{2}{|c|}{ hMSH2 and/or hMLH1(-) } & \multirow{2}{*}{$\begin{array}{c}\text { Total } \\
37\end{array}$} & \multicolumn{2}{|c|}{ hMSH2 and/or hMLH1(-) } \\
\hline & & & 3 & $(7.7)$ & & 14 & $(37.8)$ \\
\hline Age at diagnosis & $<65$ & 16 & 1 & $(6.3)$ & 15 & 6 & $(40.0)$ \\
\hline of 1 st cancer & $\geq 65$ & 23 & 2 & $(8.7)$ & 22 & 8 & $(36.4)$ \\
\hline Positive & & 30 & 2 & $(6.7)$ & 19 & 10 & $(52.6)$ \\
\hline Age at diagnosis & $<65$ & 16 & 0 & $(0)$ & 8 & 6 & $(75.0)$ \\
\hline of 1 st cancer & $\geq 65$ & 14 & 2 & (14.3) & 11 & 4 & $(36.4)$ \\
\hline
\end{tabular}

CRC alone, colorectal carcinoma alone; CRC with GC, colorectal carcinoma with gastric carcinoma; values represent the number of patients, with the percentages in parentheses.

Table IV. Types of cancer in family members and the protein expression of hMSH2 and/or hMLH1 in CRC alone or CRC with GC.

\begin{tabular}{|c|c|c|c|c|c|c|c|}
\hline \multicolumn{4}{|c|}{ CRC alone } & \multicolumn{4}{|c|}{ CRC with GC } \\
\hline \multirow{2}{*}{$\begin{array}{l}\text { Organs of cancers } \\
\text { in family members } \\
\text { Stomach }\end{array}$} & $\begin{array}{l}\text { No. of cases } \\
\text { (no. of family) } \\
\text { members) }\end{array}$ & \multicolumn{2}{|c|}{$\begin{array}{l}\text { No. of cases } \\
\text { with hMSH2 } \\
\text { and/or hMLH1(-) }\end{array}$} & \multirow{2}{*}{$\begin{array}{l}\text { Organs of cancers } \\
\text { in family members } \\
\text { Stomach }\end{array}$} & $\begin{array}{l}\text { No. of cases } \\
\text { (no. of family) } \\
\text { members) }\end{array}$ & \multicolumn{2}{|c|}{$\begin{array}{l}\text { No. of cases } \\
\text { with hMSH2 } \\
\text { and/or hMLH1(-) }\end{array}$} \\
\hline & $20 \quad(19)$ & 0 & $(0)$ & & $9 \quad(7)$ & 2 & $(22.2)$ \\
\hline Lung & $4 \quad(4)$ & 1 & $(25.0)$ & Uterus & $3 \quad(3)$ & 2 & (66.6) \\
\hline Liver & $3 \quad(3)$ & 0 & $(0)$ & Colorectum & $2 \quad(1)$ & 2 & $(100)$ \\
\hline Uterus & $1 \quad(1)$ & 0 & $(0)$ & Breast & $1 \quad(1)$ & 0 & $(0)$ \\
\hline Colorectum & $1 \quad(1)$ & 0 & $(0)$ & Others & $11 \quad(11)$ & 4 & $(36.3)$ \\
\hline Breast & $1 \quad(1)$ & 0 & $(0)$ & & & & \\
\hline Others & $9 \quad(9)$ & 1 & $(11.1)$ & & & & \\
\hline
\end{tabular}

CRC alone: colorectal carcinoma alone; CRC with GC: colorectal carcinoma; values represent the number of patients, with the percentages in parentheses.

Immunohistochemical protein expression of $h M S H 2$ and hMLH1 of GC. We examined the loss of a protein expression for hMSH2 and/or hMLH1 of GC in patients with CRC with $\mathrm{GC}$. The loss of a protein expression for hMLH1 and hMSH2 and/or hMLH1 of GC in patients demonstrating CRC with GC was recognized to be 25.0 and $26.8 \%$, respectively (Table I), though the loss of a protein expression for hMSH2 in GC was significantly less frequent than that for CRC in patients of $\mathrm{CRC}$ with $\mathrm{GC}(\mathrm{p}<0.001)$. Among the patients demonstrating $\mathrm{CRC}$ with $\mathrm{GC}$, the loss of a protein expression of $\mathrm{hMSH} 2$ and/or hMLH1 in GC and CRC tissue specimens in patients with multiple GC (MGC) was significantly more frequent than that in patients with single focal gastric carcinoma (SGC), respectively $(\mathrm{p}<0.005, \mathrm{p}<0.002$, Table V).

\section{Discussion}

The proteins encoded by the MMR genes recognize and repair base pair mismatches and the single-strand insertion/deletion loop during DNA replication, recombination, and/or chemical modification. Defective MMR gene activity leads to an accumulation of replication errors (RERs) and genetic instability, also known as a mutator phenotype, such as microsatellite instability (MSI). Maehara et al (16) discussed the relationship among the risk of cancer, MSI, and loss of hMSH2/MLH1 protein. The defective protein expression of hMSH2 and/or hMLH1 included patients, who have both MSI-H and familial cancer. In addition, it has been reported that immunohistochemistry could detect hMLH1 and hMSH2 protein abnormalities, caused by MLH1 abnormalities, including not only gene mutations (17) but also the hMLH1 promoter DNA methylation $(17,18)$ or MSI and its methylation, though the methylation of the $\mathrm{hMSH} 2$ protein demonstrated a very low frequency (19). Therefore, negative staining in the immunohistochemical analysis represents gene mutations or/ and the methylation of the hMLH1 and gene mutations of the hMSH2, a useful alternative strategy for identifying tumors with a defective MMR gene activity (20). 
Table V. Relationship between multifocal cancer lesions and the protein expression of hMSH2 and/or hMLH1 of MGC in CRC with GC.

\begin{tabular}{|c|c|c|c|c|c|c|c|}
\hline \multirow[b]{2}{*}{$\mathrm{GC}(\mathrm{n}=56)$} & \multirow[b]{2}{*}{ Total } & \multicolumn{3}{|c|}{ GC } & \multicolumn{3}{|c|}{ CRC } \\
\hline & & \multicolumn{3}{|c|}{$\begin{array}{l}\text { No. of cases } \\
\text { with hMSH2 } \\
\text { and/or hMLH1(-) }\end{array}$} & \multicolumn{3}{|c|}{$\begin{array}{l}\text { No. of cases } \\
\text { with hMSH2 } \\
\text { and/or hMLH1(-) }\end{array}$} \\
\hline SGC & 49 & 10 & (20.4) & & 17 & $(34.7)$ & \\
\hline MGC & 7 & 5 & (71.4) & $\mathrm{p}<0.005^{*}$ & 7 & $(100)$ & $\mathrm{p}<0.002^{*}$ \\
\hline
\end{tabular}

GC, gastric carcinoma; SGC, single gastric carcinoma; MGC, multiple gastric carcinomas; values represent the number of patients, with the percentages in parentheses; ${ }^{*}$ significant difference.

From 6 to $9 \%$ of all patients after a surgical resection of first CRC demonstrated a second extracolonic carcinoma $(21,22)$. In particular, a metachronous CRC after surgery for GC, and a metachronous GC after surgery for CRC were often found $(23,24)$. There have been no reports to our knowledge on the biological nature or characteristics of any specified carcinoma with double carcinomas of the stomach and colorectum. A recent study demonstrated a defective protein expression of hMSH2 and/or hMLH1 in cases of CRC alone or GC alone $(25,26)$. The frequency of defective protein expression of hMSH2 and/or hMLH1 in cases with CRC alone was $7.2 \%$ in our study and this finding closely correlated to the reported frequency of MSI or RER in sporadic CRC. MSI-H has been reported to be observed from $5-20 \%$ of sporadic CRC cases $(27,28)$. A high frequency loss of the two MMR gene proteins was observed in patients with GC and CRC. This frequency was especially high, namely up to $75 \%$ (6 of 8), in cases demonstrating CRC with GC diagnosed when patients were aged $<65$ years and also had a family history of cancers.

In Fig. 3, the survival rate in patients with the defective protein expression of $\mathrm{hMSH} 2$ and/or hMLH1 was higher than that with positive protein expression of hMSH2 and/or hMLH1 in CRC with GC (Fig. 3, p<0.05), although the survival rate of cases with defective protein expression of hMSH2 and/or hMLH1 did not differ from those cases with positive protein expression of hMSH2 and/or hMLH1 in CRC alone. Most published studies suggest that MSI-H CRC have a favorable outcome $(25,29,30)$, although not all studies agree $(31,32)$. MSI-H CRC has been reported to have a poor prognosis in other carcinomas, such as endometrial and breast carcinomas $(33,34)$. The reasons for the different survival rates were not elucidated. The reason that MSI-H CRC has a favorable outcome, could be due to a selfdestructive effect of a large accumulation of numerous mutations in the cell genome, and the biological nature of MSI and MSS. In fact, a high chemosensitivity for 5-FU in MSI-H patients has been recognized (30). Ribic et al indicated the prognosis of patients with MSI and MSS in stage II and III colon cancer (35). According to their study, the prognosis of patients with MSI-H was better than that for those with MSI-L or MSS, and the benefits of adjuvant chemotherapy (5-FU) were recognized in patients with MSS or MSI-L but not in patents with MSI-H.

A review of MGC was reported by Moertel et al (15) in 1957. The frequency of MGC was 1-3.5\% in Europe, USA and Japan. In our previous cancer center study, Morita et al (36) reported the frequency of MGC to be $6.3 \%$, and the occurrence of MGC was thus associated with a family history of GC. MGC was seen in 7 of 56 patients (12.5\%) with both CRC and GC in this study. Previously, a high rate of MSI-H was observed in MGC (37-39). The frequency of defective protein expression of hMSH2 and/or hMLH1 in MGC was significantly higher than that of SGC (Table V). We suggest that some CRC with GC cases thus belong to HNPCCassociated cancer, because the frequency of a defective protein expression of hMSH2 and/or hMLH1 in CRC with GC is higher than the frequency for patients with CRC alone, the frequency of a defective protein expression of hMSH2 and/or hMLH1 in patients, who have carcinomas of the stomach or colorectum in family members is higher than those, who have other carcinoma types (Table IV), and the frequency of MGC, related with familial history is high (Table V).

Our results suggest that hMSH2 and hMLH1 gene abnormalities play an important role in the tumorigenesis of patients demonstrating CRC with GC. The relationship between defective DNA MMR and the presence of multiple primary carcinomas in the gastrointestinal tract may thus allow to effectively screen patients at risk for developing either second or third carcinomas. Therefore, a more careful follow-up after first surgery which does not overlook secondary carcinomas, particular in patients with a defective protein expression of $\mathrm{hMSH} 2$ and/or hMLH, is called for.

\section{Acknowledgements}

We are grateful to Dr Kenichi Nishiyama (pathologist) and Ms. Ayano Yamasaki (pathological technician), National Kyushu Cancer Center, for technical assistance.

\section{References}

1. Tsukuma H, Fujimoto I, Hanai A, Hiyama T, Kitagawa T and Kinoshita N: Incidence of second primary cancers in Osaka resistants, Japan, with special reference to cumulative and relative risks. Jpn J Cancer Res 85: 339-345, 1994. 
2. Santos MC, Gardner B and Feldman J: Analysis of multiple primary cancers in a single institution. J Surg Oncol 55: 95-99, 1994.

3. Okamoto $\mathrm{N}$, Morio S, Inoue $\mathrm{R}$ and Akiyama $\mathrm{K}$ : The risk of a second primary cancer occurring in five-year survivors of an initial cancer. Jpn J Clin Oncol 17: 205-213, 1987.

4. Sasaki A, Furusawa M, Tomoda H, Seo Y, Ohno S, Morita M, Matsukima A and Kakeji Y: Evaluation of multiple cancer on patients with early gastric cancer. Jpn J Gastroenterol Surg 27: 1747-1752, 1994

5. Liu B, Parsons RE, Hamilton SR, Petersen GM, Lynch HT, Watson P, Markowitz S, Willson JKV, Green J, de la Chapelle A, Kinzler KW and Vogelstein B: hMSH2 mutations in hereditary nonpolyposis colorectal cancer kindreds. Cancer Res 54: 4590-4594, 1994.

6. Kolodner RD, Hall NR, Lipford J, Kane MF, Morrison PT, Finan PJ, Burn J, Chapman P, Earabino C, Merchant E and Bishop DT: Structure of the human MLH1 locus and analysis of a large hereditary nonpolyposis colorectal cancer kindred for mlh1 mutations. Cancer Res 55: 242-248, 1995.

7. Vasen HFA, Mecklin JP, Khan PM and Lynch HT: The international collaborative group on hereditary non-polyposis colorectal cancer (ICG-HNPCC). Dis Colon Rectum 34: 424-425, 1991.

8. Watson P and Lynch HT. Extracolonic cancer in hereditary nonpolyposis colorectal cancer. Cancer 71: 677-685, 1993.

9. Aarnio M, Mecklin JP, Aaltonen L, Nyström-Lahti M and Järvinen HJ: Life-time risk of different cancers in hereditary nonpolyposis colorectal cancer (HNPCC) syndrom. Int J Cancer 64: 430-433, 1995.

10. Vasen HFA, Wijnen JT, Menko FH, Kleibeuker JH, Taal BG, Griffioen G, Nagaengast FM, Meijers-Heijboer H, Bertario L, Varesco L, Bisgaard ML, Mohr J, Fodde R and Khan PM: Cancer risk in families with hereditary nonpolyposis colorectal cancer diagnosed by mutation analysis. Gastroenterology 110: 1020-1027, 1996.

11. Vasen HFA, Sanders EA, Taal BG, Nagengast FM, Griffioen G, Menko FH, Kleibeuker JH, Houwing-Duistermaat JJ and Khan PM: The risk of brain tumours in hereditary nonpolyposis colorectal cancer (HNPCC). Int J Cancer 65: 422-425, 1996.

12. Sijmons RH, Kiemeney LA, Witjes JA and Vasen HF: Urinary tract cancer and hereditary nonopolyposis colorectal cancer: risks and screening options. J Urol 160: 466-470, 1998.

13. TNM classification of malignant tumors (UICC). 5th edition, Wiley-Liss, New York, 1997.

14. Warren S and Gates O: Multiple primary malignant tumors. Am J Cancer 16: 1358-1414, 1932.

15. Moertel CG, Bargen JA and Soule EH: Multiple gastric cancers: Review of the literature and study of 42 cases. Gastroenterology 32: 1095-1103, 1957.

16. Maehara Y, Oda S and Sugimachi K: The instability within: problems in current analyses of microsatellite instability. Mutat Res 461: 249-263, 2001.

17. Salahshor S, Koelbel K, Rubio C and Lindblom A: Microsatellite instability and hMLH1 and hMSH2 expression analysis in familial and sporadic colorectal cancer. Lab Invest 81: 535-541, 2001.

18. Kane MF, Loda M, Gaida GM, Lipman J, Mishra R, Goldman H, Jessup JM and Kolodner R: Methylation of the hMLH1 promoter correlates with lack of expression of hMLH1 in sporadic colon tumors and mismatch repair-defective human cell lines. Cancer Res 57: 808-811, 1997.

19. Salvesen HB, MacDonald N, Ryan A, Iversen OE, Jacobs IJ, Akslen LA and Das S: Methylation of hMLH1 in a populationbased series of endometrial carcinomas. Clin Cancer Res 6: 3607-3613, 2000

20. Boland CR, Thibodeau SN, Hamilton SR, Sidransky D, Eshleman JR, Burt RW, Meltzer SJ, Rodriguez-Bigas MA, Fodde R, Ranzani GN and Srivastava S: A national cancer institute workshop on microsatellite instability for cancer detection and familial predisposition: development of international criteria for the determination of microsatellite instability in colorectal cancer. Cancer Res 58: 5248-5257, 1998.

21. Maruyama H, Hasuike Y, Furukawa J, Naoi M, Takata N, Yayoi E, Okamura J and Okamoto S: Multiple colorectal carcinomas and colorectal carcinoma associated with extracolonic malignancy. Surg Today 22: 99-104, 1992.
22. Varty PP, Delrio P and Boulos PB: Survival in colorectal carcinoma associated with previous extracolonic cancer. Ann R Coll Surg Engl 76: 180-184, 1994.

23. Lundegardh G, Hansson LE, Nyren O, Adami HO and Krusemo UB: The risk of gastrointestinal and other primary malignant disease following gastric cancer. Acta Oncol 30: 1-6, 1991.

24. Tomoda H, Taketomi A, Baba H, Kohnoe S, Seo Y and Saito T: Multiple primary colorectal and gastric carcinoma in Japan. Oncol Rep 5: 147-149, 1998.

25. Ward R, Meagher A, Tomlinson I, O'Conner T, Norrie M, Wu R and Hawkins N: Miscrosatellite instability and the clinicopathological features of sporadic colorectal cancer. Gut 48: 821-829, 2001.

26. Baek MJ, Kang H, Kim SE, Park JH, Lee JS, Paik YK and Kim H: Expression of hMLH1 is inactivated in the gastric adenomas with enhanced microsatellite instability. Br J Cancer 85: 1147-1152, 2001.

27. Percesepe A, Borghi F, Menigatti M, Losi L, Di Gregorio C, Foroni M, Rossi G, Pedroni M, Sala E, Vaccina F, Roncucci L, Benatti P, Viel A, Genuardi M, Marra G, Kristo P, Peltomaki P and Ponz de Leon M: Molecular screening for herediary nonpolyposis colorectal cancer: a prospective, population-based study. J Clin Oncol 19: 3944-3950, 2001.

28. Laiho P, Launonen V, Lahermo P, Esteller M, Herman JG, Guo M, Mecklin JP, Järvinen H, Sistonen P, Kim KM, Shibata D, Houlston RS and Aaltonen LA: Low-level microsatellite instability in most colorectal carcinomas. Cancer Res 62: 1166-1170, 2002.

29. Perrin J, Gouvernet J, Parriaux D, Noguchi T, Giovannini MH, Giovannini M, Delpero JR, Birnbarm D and Monges G: MSH2 and MLH1 immunodetection and the prognosis of colon cancer. Int J Oncol 19: 891-895, 2001.

30. Hemminki A, Mecklin JP, Järvinen H, Aaltonen LA and Joensuu H: Microsatellite instability is a favorable prognostic indicator in patients with colorectal cancer receiving chemotherapy. Gastroenterology 119: 921-928, 2000.

31. Percesepe A, Benatti P, Roncucci L, Sassatelli R, Fante R, Ganazzi D, Bellacosa A, Genuardi M, Neri G, Viel A and Ponz de Leon M: Survival analysis in families affected by hereditary nonpolyposis colorectal cancer. Int J Cancer 71 : 373-376, 1997.

32. Curran B, Lenehan K, Mulcahy H, Tighe O, Bennett MA, Kay EW, O'Donoghue DP, Leader M and Croke DT: Replication error phenotype, clinicopathological variables, and patients outcome in Dukes B stage II (T3,N0,M0) colorectal cancer. Gut 46: 200-204, 2000.

33. Caduff RF, Johnston CM, Svoboda-Newman SM, Poy EL, Merajver SD and Frank TS: Clinical and pathological significance of microsatellite instability in sporadic endometrial carcinoma. Am J Pathol 148: 1671-1678, 1996.

34. Paulson TG, Wright FA, Parker BA, Russack V and Wahl GM: Microsatellite instability correlates with reduced survival and poor disease prognosis in breast cancer. Cancer Res 56: 4021-4026, 1996.

35. Ribic CM, Sargent DJ, Moore MJ, Thibodeau SN, French AJ, Goldberg RM, Hamilton SR, Laurent-Puig P, Gryfe R, Shepherd LE, Tu D, Redston M and Gallinger S: Tumor microsatellite-instability status as a predictor of benefit from fluorouracil-based adjuvant chemotherapy for colon cancer. $\mathrm{N}$ Engl J Med 349: 247-257, 2003.

36. Morita M, Kuwano H, Baba H, Taketomi A, Kohnoe S, Tomoda H, Araki K, Saeki H, Kitamura K and Sugimachi K: Multifocal occurrence of gastric carcinoma in patients with a family history of gastric carcinoma. Cancer 83: 1307-1311, 1998.

37. Nakashima H, Honda M, Inoue H, Shibuta K, Arinaga S, Era S, Ueo $\mathrm{H}$, Mori $\mathrm{M}$ and Akiyoshi T: Microsatellite instability in multiple gastric cancers. Int J Cancer 64: 239-242, 1995.

38. dos Santos NR, Seruca R, Constancia M, Seixas M and Sobrinho-Simoes M: Microsatellite instability at multiple loci in gastric carcinoma: clinicopathologic implications and prognosis. Gastroenterology 110: 38-44, 1996.

39. Miyoshi E, Haruma K, Hiyama T, Tanaka S, Yoshihara M, Shimamoto $\mathrm{F}$ and Chayama K: Microsatellite instability is a genetic marker for the development of multiple gastric cancers. Int J Cancer 95: 350-353, 2001. 